\title{
LABOR ARBITRATION OF GRIEVANCES INVOLVING RACTAL DISCRIMINATION
}

\author{
WILJTAM B. GoULD †
}

By enacting title VII of the Civil Rights Act of $1964,{ }^{1}$ Congress acknowledged the fact that a substantial number of unions and employers were dealing unfairly with minority group workers. Hearings conducted by Senator Edward M. Kennedy highlighted the failure of many who do business with the Government to comply with prohibitions of racial discrimination theoretically imposed upon them through government contracts. ${ }^{2}$ A greater awareness of this problem has triggered administrative as well as judicial articulation of the doctrine that unions certified to represent workers within an appropriate unit owe a duty to represent such employees in a fair and just manner. ${ }^{3}$ Thus it is a lame defense to a charge of racial discrimination to contend that collective bargaining is a private affair which need only reflect the interests of the parties to the agreement: management and the union. ${ }^{4}$ The rights of minority workers can be strongly influenced by the results of collective bargaining. In particular, the arbitration clauses included in most collective bargaining agreements can have substantial impact

$\dagger$ Professor of Law, Wayne State University. A.B. 1958, University of Rhode Island; LL.B. 1961, Cornell University. Graduate Study, 1962-63, London Schoo1 of Economics. Formerly, Consultant to Equal Employment Opportunity Commission.

This article seeks to develop further the basic analysis presented in a paper read at the American Bar Association Institute of Equal Employment Opportunity Law in Washington, D.C. on March 29, 1969, reprinted in Gould, Non-Governnental Remedies for Employment Discrimination, 20 SYRACUSE L. REv. 865 (1969). Although the article equates Negro workers with minorities, it is of course clear that other groups fit into this category and that some of the same assumptions can be applied to them.

The author is indebted to James VeuCasovic of Wayne State University Law School for research assistance in the preparation of this Article.

142 U.S.C. $\$ \S 2000 \mathrm{e}-1$ to e-15 (1964).

2 N.Y. Times, Mar. 28, 1969, at 46, col. 2.

3 See Vaca v. Sipes, 386 U.S. 171, 177 (1967) ; Humphrey v. Moore, 375 U.S. 335, 342 (1964); Conley v. Gibson, 355 U.S. 41, 46 (1957) ; Ford Motor Co. v. Huffman, 345 U.S. 330, 337-38 (1953) ; Graham v. Brotherhood of Locomotive Firemen, 338 U.S. 232, 238-40 (1949) ; Tunstall v. Brotherhood of Locomotive Firemen, 323 U.S. 210 (1944); Steele v. Louisville \& N.R.R., 323 U.S. 192, 202-03 (1944); Local 12, Rubber Workers v. NLRB, 368 F.2d 12, 16-17 (5th Cir. 1966), cert. denied, 389 U.S. 837 (1967); Metal Workers Local 1, 147 N.L.R.B. 1573 (1964); Miranda Fuel Co., 140 N.L.R.B. 181, 184-85 (1962), enforcenent denied, 326 F.2d 172 (2d Cir. 1963).

4 Unions and employers violate the National Labor Relations Act, 29 U.S.C. $\$ \$ 151-158,159-168$ (1964), when they attempt to bargain to the point of impasse over an illegal demand, such as a racially discriminatory demand prohibited by title VII of the Civil Rights Act of 1964, 42 U.S.C. $\$ \$ 2000 \mathrm{e}-1$ to e-15 (1964); see NLRB v. Wooster Div. of Borg-Warner Corp., 356 U.S. 342 (1958). It is possible that $\$ 1$ of the Civil Rights Act of 1866, 42 U.S.C. $\$ 1981$ (1964), prohibits racial discrimination in employment as well as housing; see Jones v. Alfred H. Mayer Co., 392 U.S. 409, 441 n.78 (1968). See also Exec. Order No. 11,246, 3 C.F.R. 339 (1964-65). 
upon the rights of black workers who allege both racial discrimination and contract violation-rights which these legislative and doctrinal developments seek to protect.

However, considering the important role played by labor arbitration in the collective bargaining process, ${ }^{5}$ it is surprising that arbitration's potential for dealing with racial discrimination has to date received so little attention. ${ }^{6}$ In fact, commentary on the law evolving both from administrative agencies and the courts has thus far obscured the role of arbitration. ${ }^{7}$ Instead, the focus of discussion has been on public law (such as the National Labor Relations Act, ${ }^{8}$ with its duty of fair representation doctrine, and title VII ${ }^{\ominus}$ ) as a vehicle to deal with racial discrimination in employment.

One may argue that this is as it should be, since collective bargaining and arbitration are private processes essentially tailored to the needs of the parties. However, this viewpoint suggests that there is a sharp demarcation between public and private labor law, and that the obligations which have their origin in the former are not to be incorporated into the arbitral process. Supporters of this dichotomy also emphasize the availability of recently devised public law sanctions intended to help minority group workers, which should make reliance upon arbitrators unnecessary. This Article maintains there is no such sharp distinction, and even if there were, the obligation of fair representation for minority groups, developed in public law, should be enforced in private agreements by arbitrators.

5 "[A] rbitration of labor disputes under collective bargaining agreements is part and parcel of the collective bargaining process itself." United Steelworkers v. Warrior \& Gulf Navigation Co., 363 U.S. 574, 578 (1960).

- See Gould, Non-Governmental Remedies for Employment Discrimination, 20 Syracuse L. REv. 865 (1969); cf. Platt, The Relationship Between Arbitration and Title VII of the Cizil Rights Act of 1964, 3 GA. L. REv. 398, 403-06 (1969). See generally Wallen, Industrial Relations Problems of Employing the Disadvantaged, Paper delivered for $22 \mathrm{~d}$ Annual Meeting of National Academy of Arbitrators, Jan. 31, 1969. However, the general problem of arbitration and public law has been treated in Howlett, The Arbitrator, the NLRB and the Courts, in ProceEDINGS OF THE Twentieth ANNual MeEting of The National Academy of Arbitrators 67 (1967) ; Meltzer, Ruminations About Ideology, Laze and Labor Arbitration, in Proceedings of the Twentieth ANnUal MeEting of the National Academy of Arbitrators 1 (1967); and Blumrosen, Public Policy Considerations in Labor Arbitration Cases, 14 RutGers L. Rev. 217 (1960).

${ }^{7}$ See generally Aaron, The Union's Duty of Fair Representation Under the Railway Labor and National Labor Relations Acts, 34 J. AIR L. \& Com. 167 (1968); Aaron, Some Aspects of the Union's Duty of Fair Representation, 22 OHIo ST. L.J. 39, 49-54 (1961) ; Cox, The Duty of Fair Representation, 2 Vin. L. REv. 151, 161-63 (1957); Gould, Seniority and the Black Worker: Reflections on Quarles and Its Implications, 47 Texas L. REv. 1039 (1969); Gould, The Negro Revolution and the Law of Collective Bargaining, 34 FondHAM L. REv. 207 (1965); Sovern, The National Labor Relations Act and Racial Discrimination, 62 Colum. L. REv. 563 (1962). See also M. SOVERN, Legal RestratnTs on RAcial Discrinination IN EMployment (1966).

$\$ 29$ U.S.C. $\$ \S 151-58,159-67$ (1964).

842 U.S.C. $\$ 2000 \mathrm{e}-1$ to e-15 (1964). 
The principal attraction of the neat dichotomy outlined above-and its corollary treatment of arbitration as the parties' own preserve-is the resulting control which unions and employers can exercise over grievance-arbitration machinery. This principle of strong unionemployer control finds strong support both from Congress and the Supreme Court. Congress has stated explicitly that " [f] inal adjustment by a method agreed upon by the parties is . . . the desirable method for settlement of grievance disputes arising over the application or interpretation of an existing collective bargaining agreement." ${ }^{10}$ The Court has vigorously enforced this policy. In Republic Steel Corp. v. Maddox, ${ }^{11} \mathrm{Mr}$. Justice Harlan concluded for a majority of the Court that the individual worker must exhaust grievance-arbitration machinery for the redress of contract grievances before proceeding into court. He stated that if workers could "side-step" the collective agreement and file suits in court, the uniformity and orderliness of an "exclusive method" would be undermined. ${ }^{12}$ Then, in Vaca $v$. Sipes, ${ }^{13}$ the Supreme Court severely limited the role of the individual worker in cases challenging a union's decision not to process a grievance. Warning against the possibility that the parties might cease negotiating "detailed grievance and arbitration procedures" in accordance with national labor policy if the grievant could unilaterally proceed to arbitration, the Court said, "we conclude that a union does not breach its duty of fair representation, and thereby open up a suit by the employee, . . . merely because it settled the grievance short of arbitration." 14 Thus the Court not only reaffirmed the Maddox exhaustion requirements, but also concluded that an individual worker has no right to proceed to arbitration. The vice was further tightened when the Court later in the case addressed itself to an individual worker's right to sue in court subsequent to processing his grievance through the machinery:

[W] think the wrongfully discharged employee may bring an action against his employer in the face of a defense based upon the failure to exhaust contractual remedies, provided the employee can prove that the union as bargaining agent breached its duty of fair representation in its handling of the employee's grievance. . . .

10 Labor-Management Relations Act $\$ 203$ (d), 29 U.S.C. $\$ 173$ (d) (1964) [hereinafter cited as Taft-Hartley Act]; see United Steelworkers v. Enterprise Wheel \& Car Corp., 363 U.S. 593, 596 (1960) ; United Steelworkers v. Warrior \& Gulf Navigation Co., 363 U.S. 574, 581 (1960); United Steelworkers v. American Mfg. Co., 363 U.S. 564, 566 (1960); Textile Workers Union v. Lincoln Mills, 353 U.S. 448, 455-56 (1957).

11379 U.S. 650 (1965).

$12 I d$. at 653.

13386 U.S. 171 (1967).

14386 U.S. at 192. 
[I]t is obvious that the courts will be compelled to pass upon whether there has been a breach of the duty of fair representation in the context of many $\S 301$ breach-of-contract actions. If a breach of duty by the union and a breach of contract by the employer are proven, the court must fashion an appropriate remedy. ${ }^{15}$

With a heavy and repressive hand $V$ aca imposes upon the worker the burden of proving that the union has breached its duty of fair representation ${ }^{16}$ before the matter may be pursued in court. However, the logic involved is noteworthy. So intertwined are the public and private law considerations in labor grievances that $V a c a$ will not permit a plaintiff to recover on a privately negotiated contract without first showing violation of a statutory duty. A major theme of this Article is that title VII, and the legislative motives and assumptions behind its enactment, should expand the rights of minority group workers before arbitrators as well as the courts. Any objection to this expansion based on the asserted dichotomy of public and private law is compromised by the logic of $V a c a$. The demarcation line between these public and private functions becomes increasingly artificial.

\section{The Shortcomings of Arbitration}

\section{A. The Glover Case}

Neither Maddox nor Vaca involved racial discrimination. However, in Glover v. St. Louis-San Francisco Railway Co., ${ }^{17}$ the Court, in one of its first cases involving both duty of fair representation and contract interpretation, ${ }^{18}$ indicated that there are some limits to the Maddox-Vaca guidelines.

In Glover, thirteen workers-eight Negroes and five whitesbrought against the union and the company an action alleging that both parties discriminatorily refused to promote Negro workers to the classification of carman. Because their promotional opportunities were also impaired by the alleged practices, white workers joined in the suit. Subsequent to the defendant's motion to dismiss for failure to exhaust the grievance machinery available in the labor contract, in the union's constitution, and before the National Railroad Adjustment Board, plaintiffs amended their complaint to say that Negro workers had "called upon" the union to process grievances, but that no action had

15 Id. at 186-87 (emphasis added) (footnote omitted).

${ }^{16}$ Cases cited note 3 supra \& accompanying text.

17393 U.S. 324 (1969).

18 For earlier cases concerning the issues of both fair representation and contract interpretation, see Humphrey v. Moore, 375 U.S. 335 (1964) ; Conley v. Gibson, 355 U.S. 41 (1957). 
been taken. Moreover, it was alleged that "other representatives" of the union had told the Negro plaintiffs, "(a) that they were kidding themselves if they thought they could ever get white men's jobs; (b) that nothing would ever be done for them; and (c) that to file a formal complaint with the Brotherhood or with the Company would be a waste of their time." 19 In the amended complaint, similar responses were alleged to have been made by both the union and the company.

One might think that both Maddox and $V a c a$ would be persuasive authority for resort to contractual procedures. However, $V a c a$, in further explaining the Maddox exhaustion rules, indicated that there would be some exceptions to its general rule.

[I]t is settled that the employee must at least attempt to exhaust exclusive grievance and arbitration procedures established by the bargaining agreement. Republic Steel Corp. v. Maddox. However, because these contractual remedies have been devised and are often controlled by the union and the employer, they may well prove unsatisfactory or unworkable for the individual grievant. The problem then is to determine under what circumstances the individual employee may obtain judicial review of his breach-of-contract claim despite his failure to secure relief through the contractual remedial procedures.

An obvious situation in which the employee should not be limited to the exclusive remedial procedures established by the contract occurs when the conduct of the employer amounts to a repudiation of those contractual procedures. Cf. Drake Bakeries v. Bakery Workers . . . . In such a situation (and there may of course be others), the employer is estopped by his own conduct to rely on the unexhausted grievance and arbitration procedures as a defense to the employee's cause of action.

We think that another situation when the employee may seek judicial enforcement of his contractual rights arises if, as is true here, the union has sole power under the contract to invoke the higher stages of the grievance procedure, and if, as is alleged here, the employee-plaintiff has been prevented from exhausting his contractual remedies by the union's wrongful refusal to process the grievance. It is true that the employer in such a situation may have done nothing to prevent exhaustion of the exclusive contractual remedies to which he agreed in the collective bargaining agreement. But the employer has committed a wrongful discharge in breach of that agreement [in a $V a c a$-type case], a breach which could be remedied through the grievance process to the employee- 
plaintiff's benefit were it not for the union's breach of its statutory duty of fair representation to the employee. To leave the employee remediless in such circumstances would, in our opinion, be a great injustice. ${ }^{20}$

Thus, the Glover court reasoned that it would be a futile act to pursue contract remedies controlled by those very individuals from whose discriminatory actions the plaintiffs seek relief. But Mr. Justice Black's opinion for the Court is not entirely dependent upon the fact that the union and employer, "acting in concert," control the adjudicative machinery. That rationale, perhaps implicit in the title VII cases rejecting the exhaustion doctrine, ${ }^{21}$ would exempt a good portion of all racial discrimination cases from $M a d d o x$ and $V a c a$, especially where both unions and employers are necessarily implicated, such as in seniority and promotion matters.

Such a wide interpretation of the Glover rationale, however, is forestalled by the heavy emphasis on the union hostility alleged in the amended complaint. As the Court said: "[T] attempt to exhaust contractual remedies, required under Maddox, is easily satisfied by petitioners' repeated complaints to company and union officials, and no time-consuming formalities should be demanded of them." 22 Although eager plaintiffs may be willing to make liberal use of allegations such as those used in Glover, the hostility rationale would not permit blanket application of the Glover restlt to all racial discrimination cases-even to all those involving seniority disputes.

20386 U.S. at $184-86$ (citations omitted).

21 Cf. King v. Georgia Power Co., 295 F. Supp. 943, 949 (N.D. Ga. 1968) ; Reese v. Atlantic Steel Co., 282 F. Supp. 905, 906 (N.D. Ga. 1967); Dent v. St. LouisS.F. Ry., 265 F. Supp. 56, 57-58 (N.D. Ala. 1967), rev'd on other grounds, 406 F.2d 339 (5th Cir. 1969). However, in these cases, the plaintiffs did not allege that the racial discrimination was itself a violation of the labor contract. Where that allegation has been made, Glover has not been applied in the absence of a showing that resort to contractual procedures would be futile. See Waters v. Wisconsin Steel Works of International Harvester Co., 71 L.R.R.M. 2886 (N.D. Ill. 1969) ; cf. NLRB v. Union of Marine Workers, 391 U.S. 418, 425-28 (1968) ; Brady v. TWA, 401 F.2d 87 (3d Cir. 1968), cert. denied, 393 U.S. 1048 (1969).

Glover also involves the question whether administrative remedies available under the Railway Labor Act deprive a federal district court of jurisdiction. Proceeding upon the assumption that Congress provided for a "new and enlarged basis for elimination of racial and other discriminations in employment" the Eighth Circuit held that a federal district court is not deprived of jurisdiction in a dispute involving racial discrimination and "assignment, classification, terms and conditions of employment. These are statutory rights, not contractual rights embodied in collective bargaining agreements." Norman v. Missouri Pac. R.R., 71 L.R.R.M. 2940, 2948 (8th Cir. 1969); see Dent v. St. Louis-S. F. Ry. Co., stipra, at 57-58 Previously, in duty of fair representation cases courts dismissed complaints involving racial discrimination where the subject matter was within the jurisdiction of the Railway Labor Act. E.g., Howard v. St. Louis-S. F. Ry. Co., 361 F.2d 905 (8th Cir,), cert. denied, 385 U.S. 986 (1966). See, however, the views of Mr. Justice Black in Brotherhood of R.R. Trainmen v. Howard, 343 U..S. 768, 774 (1952) ; cf. Foy v. Norfolk \& West. Ry., 377 F.2d 243 (4th Cir.), cert. denied, 389 U.S. 848 (1967).

22393 U.S. at 331 (emphasis added). 


\section{B. Institutional Deficiencies of Arbitration of Racial Discrimination Grievances}

The Supreme Court would have been justified in painting arbitration of racial discrimination cases with a broader brush than was used in Glover. Racial discrimination is one of the "circumstances" where, in the language of $V a c a$, control of the process by the union and employer makes the process "unsatisfactory or unworkable" for the employee, and where another forum should hear the case, unhampered by the severe limitations which $V$ aca imposes upon judicial review.

First, it is obvious that the aggrieved worker or group cannot expect to obtain an objective evaluation of the issue in dispute if the parties who are alleged to have discriminated have control of the grievance machinery. Nor is the situation substantially altered if the grievance is processed to an "impartial" arbitrator rather than a unionemployer committee. ${ }^{23}$ In a union in which the leadership is not representative of minority workers, the arbitrator is in effect chosen by the discriminators and not by the discriminatee. While there are few dishonest or corrupt arbitrators, it is nevertheless difficult to ignore the pressures at work. One cannot envisage much of a chance for the Negro grievant, whom the parties often regard as disruptive and unstable, when the arbitrator owes his position to the union and the employer.

Second, black workers are almost totally absent from positions of leadership in organized labor, even in unions where their numbers are high. ${ }^{24}$ Thus, one cannot yet assume that minority group

23 The NLRB in Denver-Chicago Trucking Co., 132 N.L.R.B. 1416 (1961), ruled that "the procedures adopted [for union-employer grievance committees must] meet normal standards as to sufficiency, fairness, and regularity" and that there must not be "evidence of irregularity, collusion, or inadequate provisions for the taking of testimony." Id. at 1421 . Where these conditions have been met, the Board has sustained the committees' decisions. But wherever there is evidence of unfair practices resulting in a discharge, the Board has reinstated discharged employees. Compare Eazor Express, Inc., 172 N.L.R.B. No. 201, 69 L.R.R.M. 1081 (1968); Mitchell Transp., Inc., 152 N.L.R.B. 122, 123, 130-31 (1965) ; Northside Elec. Co., 151 N.L.R.B. 34, 35 n.1 (1965) ; Modern Motor Express, Inc, 149 N.L.R.B. 1507, 1510-12 (1964); Roadway Express, Inc., 145 N.L.R.B. 513, 514 (1963); Teamsters Local 414, 142 N.L.R.B. 273, 282-283 (1963) with Hoisting Eng'rs Local 701, 152 N.L.R.B. 49 (1965) (discharged employee need not resort to grievance machinery because grievance committee was composed of those who had discriminated); Precision Fittings, Inc., 141 N.L.R.B. 1034, 1041 (1963) and Gateway Transp. Co., 137 N.L.R.B. 1763 (1962) (a 48-hour notice of hearing, refusal of union's counsel to represent its member, and denial of employee's request for a continuance made procedure unfair). In DC' Int'1, Inc., 162 N.L.R.B. 1383 (1967), although the trial examiner found that the procedures of the arbitration committee were regular, the committee had not heard evidence on the crucial issue of pretextual discharge. The Board considered this issue, found it to be an unfair labor practice, and set aside the decision of the arbitration committee.

24 See Steelworkers Debate Black Representation, 91 Manthly LaB. REv. 16-17. However, most recently, a new union with black leadership has been formed called the National Council of Wholesale, Retail, Office and Processing Workers of America, to be aligned with the Alliance for Labor Action composed of the UAW 
grievances will be dealt with more sensitively, because their representatives have been integrated into positions of some responsibility. Although encouraging, partial integration in the lower ranks of union leadership has yet to establish real representation in decision-making. Indeed, lack of Negro leadership in the unions evidences in part the racial discrimination in American employment which prompted Congress to pass title VII in 1964.

Third, although the facts in Glover may be to the contrary, quite often the collective bargaining agreement does not support legitimate grievances asserted by protesting black workers. The cause of action is far more often founded in public law concepts, such as the duty of fair representation or title VII. This pattern of conflict between public law and contract makes incomprehensible the National Labor Relations Board's holding in Local 12, Rubber Workers ${ }^{25}$ that the union must carry protests against an allegedly discriminatory seniority system to arbitration. ${ }^{26}$ Moreover, the seniority agreement itself may incorporate discriminatory practices. While Mr. Justice Fortas in his concurring opinion in Vaca indicated that an order compelling arbitration was "[p] recisely and uniquely the kind of order which is within the province of the Board," ${ }^{27}$ it would appear from the words of the statute to be a function of the judiciary operating under section 301 of the Taft-Hartley Act. ${ }^{28}$ The problem is that Negro workers are delivered up to the very contract against which they have complained. Until the arbitration process is revised, one cannot expect the holding in Rubber Workers to contribute to their job advancement.

Even where there is a no-discrimination clause prohibiting discrimination on the basis of race-and even where the clause has been negotiated subsequent to the passage of civil rights legislation-arbitrators are generally reluctant to rely upon public law concepts in their opinions and awards. The primary reason for this attitude is the wellaccepted notion that the arbitrator is a creature of the parties and is commissioned to interpret their wishes. Therefore, he is not to impose the public policies of society upon them. Moreover, unlike the judiciary, which has the authority to set aside awards which conflict

and the International Brotherhood of Teamsters. "The top office, either chairman or president, is expected to go to a Negro; Cleveland Robinson, secretary-treasurer of District 65, [formerly a part of the AFL-CIO Retail-Wholesale Union] is a likely choice." Wall Street Journal, May 23, 1969, at 4, col. 2-3.

25150 N.I.R.B. 312 (1954), enforced, 368 F.2d 12 (5th Cir. 1966), cert. denied, 389 U.S. 837 (1967).

26 See id.; cf. Local 485, Elec. Workers, 170 N.L.R.B. No. 121, 67 L.R.R.M. 1609 (1968) ; Port Drum Co., 170 N.L.R.B. No. 51, 67 L.R.R.M. 1506 (1968); Gould, The Negro Revolution and the Law of Collective Bargaining, 34 FordHAM I. Rev. 207, 226-30 (1965). 
with law, ${ }^{29}$ the arbitrator does not necessarily have special training in law-let alone an expertise in the fast moving complexities of labor and civil rights law. As the Supreme Court instructed in United Steelworkers v. Enterprise Wheel \& Car Corp., ${ }^{30}$

$\mathrm{He}$ [the arbitrator] may of course look for guidance from many sources, yet his award is legitimate only so long as it draws its essence from the collective bargaining agreement. When the arbitrator's words manifest an infidelity to this obligation, courts have no choice but to refuse enforcement of the award. ${ }^{31}$

What is the role of the arbitrator who is appointed to interpret a clause which may have a discriminatory impact? May the arbitrator rely upon the no-discrimination clause or a separability clause (which assumes that the unlawful clauses in the contract are to be separated out by someone, in order that the relationship between the parties remain sound and intact) to overrule, for instance, discriminatory seniority clauses? Arbitrators have not been hesitant to fashion the remedy of injunction and damages for the no-strike clause, ${ }^{32}$ or back pay for a discharge without just cause ${ }^{33}$ despite the absence of specific authority in the collective bargaining agreement. However, the acceptability of

29 See Monroe Sander Corp. v. Livingston, 377 F.2d 6, 13 (2d Cir. 1967) (dictum); McGuire v. Humble Oil \& Refining Co., 355 F.2d 352, 358 (2d Cir.), cert. denied, 384 U.S. 988 (1966) ; Glendale Mfg. Co. v. Local 520, ILGWU, 283 F.2d 936, 938-39 (4th Cir. 1960), cert. denied, 366 U.S. 950 (1961); Local 985, UAW v. W. M. Chace Co., 262 F. Supp. 114, 117-19 (E.D. Mich. 1966). For a discussion of the conflict between arbitration and public policies, see Local 453, Elec. Workers v. Otis Elevator Co., 206 F. Supp. 853 (S.D.N.Y.) \& 201 F. Supp. 213 (S.D.N.Y. 1962) ; Black v. Cutter Laboratories, 43 Cal. 2d 788, 278 P.2d 905 (1955), appeal dismissed, 351 U.S. 292 (1956). See generally Blumrosen, Public Policy Considerations in Labor Arbitration Cases, 14 Rutgers L. Rev. 217 (1960) ; Dunau, Three Problems in Labor Arbitration, 55 VA. I. REv. 427, $439-47$ (1969); Sovern, Section 301 and the Primary Jurisdiction of the NLRB, 76 HARV. L. REV. 529 (1963).

30363 U.S. 593 (1960).

$31 \mathrm{Id}$. at 597.

32 See New Orleans S.S. Ass'n v. Local 1418, Longshore Workers, 389 F.2d 369, 370 (5th Cir.), cert. denied, 393 U.S. 828 (1968); Tanker Serv. Comm., Inc. v. International Organization of Masters, $269 \mathrm{~F}$. Supp. 551 (E.D. Pa. 1967) ; Ruppert v. Egelhofer, 3 N.Y.2d 576, 580-81, 148 N.E.2d 129, 130 (1958); Ford Motor Co., 41 Lab. Arb. 619 (1963) ; cf. Safeway Stores v. Local 111, Bakery Workers, 390 F.2d 79, 80-81 (5th Cir. 1968); Philadelphia Marine Trade Ass'n v. Local 1291, Longshoremen, 365 F.2d 295, 296-97 (3d Cir. 1966), rev'd on other grontsds, 389 Ü.S. 64 (1967); Gulf \& S. Am. S.S. Co. v. National Maritime Union, 360 F.2d 63, 64 (5th Cir. 1966).

33 See International Harvester Co., 9 Lab. Arb. 894 (1947) ; cf. Consolidated Paper Co., 33 Lab. Arb. 840 (1959) ; United States Indus. Chem. Co., 33 Lab. Arb. 335 (1959); Elberta Crate \& Box Co., 32 Lab. Arb. 228 (1959) ; International Paper Co., 31 Lab. Arb. 494 (1958) ; United States Rubber Co., 13 Lab. Arb. 839 (1949). One of the more extraordinary arbitral remedies issued to date is Jack Meilman, 34 Lab. Arb. 771 (1960), where the arbitrator ordered a company to cease operations at its new location, to reestablish its operation where it had formerly operated, and to pay damages to the union for wages and other contract benefits lost by the company's breach of contract. See generally Fleming, Arbitrators and the Remedy Power, 48 VA. L. REv. 1199 (1962). 
these decisions is attributable to the fact that they are in accord with the parties' conscious and subconscious expectations. In the case of discriminatory grievances, all of the factors indicate that the parties view minority group members as a disruptive intrusion into what might otherwise be a smooth-working bilateral arrangement. ${ }^{34}$ This attitude is certainly prevalent in some seniority disputes, ${ }^{35}$ although in the area of discipline and discharge one suspects that the union (and sometimes the employer) views the process of frivolous grievances as a harmless effort which releases the union from the snares of duty of fair representation suits. Ordinarily, however, the parties do not intend arbitrators to function as a mini-Equal Employment Opportunity Commission. Accordingly, in most instances the parties do not view the nodiscrimination clause as a grant of authority alkin to the no-strike and discharge clauses.

[I]t may be possible for arbitrators, as well as courts, to invalidate a discriminatory clause on the theory that the parties cannot be assumed to have intended to act illegally. But insofar as arbitrators are concerned, the violation should be clearly unlawful and the remedy uncomplicated. If these ingredients are not present, the arbitrator will be too far in front of the contract expectations of labor and management. ${ }^{36}$

Some arbitrators themselves maintain that the violation of law must be very clear in order that the arbitrator's bonds be loosened, ${ }^{37}$ although others would prefer to avoid the risk of rubber-stamping discrimination when the issue smacks of race. ${ }^{38}$ However, even with the latter group the problems are by no means solved. Racial discrimination

34 As Judge J. Skelly Wright said in an unfair labor practice case arising under the National Labor Relations Act:

The company did agree to a general non-discrimination clause. However, the Examiner could reasonably have found that such a clause meant little if the company would not also work to correct individual grievances. See Local Union No. 12, United Rubber etc. Workers v. N.L.R.B., 5 Cir., 368 F.2d 12, 14 . : (1966), cert. denied, 389 U.S. $837 \ldots$ (1967), where the collective bargaining agreement provided for non-discriminatory seniority for employees but where "[a]s a matter of custom and interpretation *** Negro employees with greater seniority had no rights over white employees with less seniority ***"

United Packinghouse Workers v. NLRB, 70 L.R.R.M. 2489, 2493 n.10 (D.C. Cir. 1969). For a discussion of this case, see Gould, The Emerging Law Against Racial Discrimitation, 64 Nw. U.L. REv. - (1969).

35 See generally Gould, Employment Security, Seniority and Race: The Role of Title VII of the Civil Rights Act of 1964, 13 How. L.J. 1 (1967) ; Gould, Seniority and the Black Worker: Reflections on Quarles and its Implications, 47 TEXAS L. REv. 1039 (1969).

36 Gould, Non-Govermmental Rentedies for Employment Discrimination, supra note 6 , at $872-73$.

37 See, e.g., Ingraham Co., 48 Lab. Arb. 884, 889 (1966).

38 See Platt, The Relationship Between Arbitration and Title VII of the Civil Rights Act of 1964, supra note 6, at 407-10. 
(especially the northern ghetto variety) possesses a subtle and elusive quality with which even the most sympathetic arbitrator may not be equipped to deal. This is a fundamental reason for the existence of expert administrative agencies such as the National Labor Relations Board and the Equal Employment Opportunity Commission. Moreover, since the arbitrator is probably not trained in labor and civil rights law, the potential for error increases. This sad fact is illustrated dramatically by the arbitrator's award in Hotel Employers' Association. ${ }^{39}$ The arbitrator there boldly stated that a statistical analysis of minority groups by job classification is immaterial unless used to establish an unlawful preference for minority group workers. ${ }^{40}$ This, of course, will come as a great surprise to agencies such as the EEOC which rely upon and, in fact, require submission of statistics concerning minority group participation in the work force, under a statute prohibiting preferential treatment. ${ }^{41}$

Although arbitrators may blunder and stumble when the issues presented are foreign to their expertise, nevertheless it is too late to reject this process as a means of resolving discrimination claims. Arbitration has achieved legal respectability through the Supreme Court's endorsement of a standard which compels a resisting party to proceed to arbitration in practically every instance that the other party desires it. ${ }^{42}$ Furthermore, the NLRB has refused to set aside arbitration awards dealing with unfair labor charges if the proceedings "have been fair and regular, all parties [have] agreed to be bound, and the decision of the [arbitrator] is not clearly repugnant to the purposes and policies of the [National Labor Relations] Act." 43 It is anomalous that the Board accords such deference to arbitration in light of the reception given to public law by arbitrators. Insofar as title VII is concerned, it is especially dangerous to leave this garden untended when one considers the critical issues involved. Arbitration is an established part of the collective bargaining process. It is vital to insure it is a sound one. New approaches to the use of arbitration in grievances involving racial discrimination are needed. For if racial discrimination cases cannot be heard by arbitrators, the uniformity to which $V$ aca has given honor and consideration will be undermined by a dual system composed of public and private routes-the first for racial cases and the second for nonracial. Glover, despite its virtues, has already moved us in this

3947 Lab. Arb. 873 (1966).

$40 \mathrm{Id}$. at 885 .

411967 EEOC Ann. Rer. 21-35.

42 See cases cited note 10 supra. For varying positions on the desirability of this rule and the arbitration process, see $R$. Flemrng, THE LABOR ARBITRATION Process (1965) ; P. Hays, Labor Arbitration: A Dissenting View (1966).

43 Spielberg Mfg. Co., 112 N.L.R.B. 1080, 1082 (1955). 
direction. The Court's opinion highlights the deficiencies of $V a c a$ and its overly stringent limitations upon any individual's ability to sue both union and employer. In part, the crises of racial discrimination has made it simply impossible to apply narrowly the rules of Vaca to this important problem.

Moreover, arbitrators are infinitely more capable than government officials and judges in interpreting labor contracts and fashioning remedies. As the Supreme Court said in United Steelworkers v. Warrior \& Gulf Navigation Co., "The ablest judge cannot be expected to bring the same experience and competence to bear upon the determination of a grievance [as an arbitrator], because he cannot be similarly informed." 44

Finally, it is a plain fact that there is no clear avenue of redress for the Negro worker who attempts to cope with racial discrimination in employment today. Slow moving, understaffed, and overlapping agencies, ${ }^{45}$ coupled with Congress's failure to provide the EEOC with cease and desist powers, ${ }^{46}$ have made the urban powder keg even more explosive. If arbitration can be adapted to cope with racial discrimination, a relatively expeditious forum for the redress of grievances would then be available.

To date, EEOC has no defined policy toward labor arbitration. ${ }^{47}$ The balance of this Article discusses a number of issues posed by the present system of arbitration of discrimination cases, and offers pro-

4463 U.S. 574, 582 (1960).

45 Brookings Institute, Jobs and CiviL Rights Report FoR U.S. Civil Rights Commission (1969) [hereinafter cited as Jons AND CIVIL RIGHTs]. The failure of EEOC conciliation efforts to date is set forth in Note, Discrimination in Employment and in Housing: Private Enforcement Provisions of the Civil Rights Acts of 1964 and 1968, 82 HaRv. L. REv. 834 (1969).

46 See Jobs and CrvIL Rrgitss, supra note 45 , for a history of the legislative proposals on this subject. The current proposal to give the EEOC cease and desist powers was introduced by Senator Philip Hart (D. Mich.). S. REP. 2029, 91st Cong., 1st Sess. (1969). President Nixon has now proposed that the Commission's powers be broadened. N.Y. Times, Aug. 9, 1969, at 1, col. 5 .

47 See Deferral to Arbitration, Opinion Letter of EEOC General Counsel, Oct. 20, 1966, in 6 LABor Policy AND Practice $401: 3028$.

While the Commission is sympathetic to the principal of deferral to contractual grievance and arbitration machinery, the statutory time table prescribed by Title VII does not allow for such action. Section 706(d) arid (e) of the Act require that in cases where deferral to a State Fair Employment Practice Commission is not warranted, as is the case with an allegation of discrimination based on sex in California, the charge must be filed within 90 days of the alleged unlawful employment practice. . . . [W] consider that it is beyond the province of the Commission to itself derogate from the statutory command by deferring pending charges beyond the prescribed time.

We have, however, concluded that where the charging party and the respondents consent to have the Commission stay its proceedings by executing waivers, the Commission may elect to honor such requests for a reasonable period. While your letter indicates that the respondent would be interested in executing such a waiver, we have received no indication that the charging party would likewise be interested in a stay of the Commission's proceedings. 
posals for updating the process, while bearing in mind the difficulties of both preserving self-reliant industrial government and, at the same time, protecting black workers against employment discrimination.

\section{Election of Remedies}

While Glover can be read to exempt from the clutches of Maddox and $V a c a^{48}$ much of what is covered by title VII, there is another problem presented by the interplay between public law and private arbitration processes. What are the public law implications of resort to the grievance process by the individual or group? More specifically, does the employee make an election of remedies by utilizing the grievancearbitration machinery, and thereby waive his right to a title VII remedy issued by a court?

Courts have come to different conclusions on this matter. The first decision-and the most severely limiting to the grievant-is Bowe v. Colgate-Palmolive Co. ${ }^{49}$ In Bowe the court applied a strict election of remedies test which prevents the individual from proceeding in court under title VII once the grievance-arbitration process has been utilized. The court stated:

It was and is the Court's view and conclusion that the plaintiffs, whether named or in the class, should not and may not have two different opportunities in two different appropriate forums for presentation and litigation of their claims. It would be inequitable and unconscionable to subject the defendant Colgate to two series of extensive litigation, one series in this Court and then another series under the labor contract. ${ }^{50}$

In Washington v. Aerojet-General Corp. ${ }^{51}$ where a reprimand and one month's disciplinary layoff were involved, the court reached the same result as in Bowe, but modified the procedural restrictions. In Washington, the company and the union, with the concurrence of the plaintiff, agreed to reduce one month's disciplinary layoff to nine days at the third step of the grievance procedure. The court, noting that the plaintiff had available to him two different avenues-legislative and contractual-for the redress of his grievance, held that the plaintiff had made a binding election of remedies. However, the court balked at accepting the Bowe rationale wholesale:

48 Text accompanying notes $11-13$ supra.

49272 F. Supp. 332 (S.D. Ind. 1967).

$50 \mathrm{Id}$. at $366-67$.

51282 F. Supp. 517 (C.D. Cal. 1968). 
[T] he Court differs with the apparent implication of Bowe that there must be a strict and $a b$ initio "election of forum" made between contractual remedies under the collective bargaining agreement and Title VII remedies under the Civil Rights Act of 1964 prior to seeking either remedy. Because of the time limits under the civil rights legislation, the charging party will often be forced to initiate civil rights proceedings with the State or Federal agency or the Federal courts at precisely the same time that he is seeking to enforce his contractual rights under the collective bargaining agreement. ${ }^{52}$

Holding that the plaintiff made a binding election by accepting the company-union settlement and going back to work, the court articulated its version of the election of remedies rule:

Initially he [the plaintiff] may pursue his remedies in both forums but at some point a choice must be made. This point, as in the case of concurrent jurisdiction between State and Federal courts, is reached when a litigant has pursued his remedies in one forum to decision, be it by settlement, the decision of an arbitrator, or the decision of a judge. Such a rule is not only consonant with that applied in an analogous area, but also will contribute to the expeditious resolution of disputes in the equal employment area and promote the sound and equitable administration of justice by precluding an aggrieved party from subjecting a defendant to multiple actions based upon the same claim. ${ }^{33}$

In Edwards v. North American Rockwell Corp. ${ }^{54}$ the court was confronted with a claim for loss of straight time pay for twenty-seven hours as a result of a suspension. Before the suit, a settlement was made, and the plaintiff cashed a check for the amount authorized by the parties. The court followed Washington and stated that since "the plaintiff has pursued her contractual remedy to its conclusion, [and] has accepted the settlement reached in that proceeding, . . . [she] must be considered to have made a binding election." 55 Thus Edwards implicitly questions the Bore holding that a binding election "is made by simply initiating the grievance machinery under a collective bargaining contract." 56

Dewey v. Reynolds Metal Co., ${ }^{57}$ involving an employee against whose allegation of religious discrimination an arbitrator ruled ad-

02 Id. at 522.

$63 I d$. at 523.

54291 F. Supp. 199 (C.D. Cal. 1968).

$65 I d$. at 209.

$56 I d$. at 208.

57291 F. Supp. 786 (W.D. Mich. 1968). See also Rosenfeld v. Southern Pac. Co., 293 F. Supp. 1219, 1225 (C.D. Cal. 1968). 
versely, is the most recent case. It departs substantially from the approach taken in either Bowe, Washington, or Edwards. In Dewey, the court noted that the arbitrator was limited to an interpretation of the bargained agreement, and that at no time did the arbitrator address himself to the statutory and constitutional issues involved. The court reasoned that to preclude the plaintiff from proceeding in court under title VII subsequent to the arbitration decision would penalize workers for using contractual procedures, a practice favored by national labor policy:

[T] he arbitration award should not preclude an action in this court based upon a statute rather than the collective bargaining agreement. To hold otherwise would be to require the employee to have come to this court without attempting a settlement through the contractual processes, as preferred by the national labor law. Plaintiff would also have been required to choose between two different remedies when both remedies are provided to insure that plaintiff's contractual, statutory and constitutional rights are protected. When rights of this type are involved, they outweigh the interest of the companydefendant in avoiding the inconvenience and expense of multiple actions. ${ }^{58}$

The Bowe doctrine, on the other hand, is almost Draconian. For as Washington points out, time limits for filing a charge under title VII and state fair employment legislation make it difficult for the plaintiff to choose in any really informed manner the forum in which to proceed. Therefore, both Washington and Edwards correctly state that merely filing a grievance should not operate as a binding election of remedies that would preclude title VII litigation. It is possible, for instance, that a plaintiff-grievant will not have a proper appreciation of which forum is more appropriate until the management or the union representative responds to the grievance. The same is true of the EEOC's investigations and conciliation procedures. ${ }^{59}$ Although not discussed in Washington or Edwards, an additional factor is the enormous pressure that $V$ aca gives the union to bring to bear upon individual employees to obtain their concurrence. Suppose that the grievance might not be

$58 \mathrm{Id}$. at 789. The Board has plenary, although not exclusive, authority to remedy unfair labor practices. Carey v. Westinghouse Elec. Corp., 375 U.S. 261, 268 (1964); Smith v. Evening News Ass'n., 371 U.S. 195, 197-98 (1962). The Civil Rights Act of 1964 , tit. VII, $\$ 706(\mathrm{~g})$, 42 U.S.C. $\$ 2000 \mathrm{e}-5(\mathrm{~g})(1964)$, which provides a district court with authority to act in the public interest, is analogous to $\$ 10$ of the National Labor Relations Act, 29 U.S.C. $\$ 160$ (1964) ; cf. Jenkins v. United Gas Corp., 400 F.2d 28 (5th Cir. 1968) ; United Steelworkers v. American Int'l Aluminum Corp., 334 F.2d 147 (5th Cir. 1964), cert. demied, 379 U.S. 991 (1965); Hall v. Werthan Bag Corp., 251 F. Supp. 184 (M.D. Tenn. 1966) ; Amalgamated Ass'n of Street Employees v. Trailways of New England Inc., 232 F. Supp. 608 (D. Mass. 1964), aff'd, 343 F.2d 815 (1st Cir.), cert. denied, 382 U.S. 879 (1965).

5942 U.S.C. $\S \S 2000 \mathrm{e}-5(\mathrm{a}), 8$ (1964). 
processed past the second or third step of the procedure. What is to become of the plaintiff whose grievance is not taken to arbitration but is instead left unsettled? Presumably, Bowe would bind the unlucky worker for making the wrong election. Suppose also, that a union purports to take an objective position between the respective seniority claims of black and white workers and then blacks become convinced, after the second or third step, that the union has begun to undermine their position. The union then, courtesy of $V a c a$, and without the consent of the Negro workers, proceeds to arbitration. Does Bowe impose the election of remedies here? After all, the black workers may have initiated the grievance procedure at its incipient stages. However, under $V a c a$ it is the union which exercises discretion in deciding which cases should go to arbitration, regardless of whether the affected group initiated the grievance.

Presumably, all parties involved may consent to waive the statutory time limitations set out in title VII while the grievance is processed. ${ }^{80}$ However, it is unlikely that the party charged with discrimination would be willing to sign such a waiver since its interests are opposed to exposing itself to liability more than once. Indeed, the limited judicial review established by $V$ aca to encourage parties to use the grievance arbitration machinery has equal applicability, as a practical matter, to title VII. Obviously, parties would be reluctant to enter into settlements or proceed to arbitration when the result is ignored or used as a plateau for a better deal in a subsequent proceeding.

While one can sympathize with the position of unions and employers who wish to negotiate a final settlement, it is important to understand that arbitration is the quid pro quo for the strike and is not, as we have seen, the most suitable process for the consideration of racial discrimination grievances. One must assume that Congress passed title VII in part because the grievance-arbitration machinery was not an adequate forum for redress. Both Glover and the line of cases making exhaustion requirements inapplicable to title VII ${ }^{\text {i }}$ are consistent with this view of Congressional motivation. note 47

60 See Deferral to Arbitration, Opinion Letter of EEOC General Counsel, supra

61 See note 21 supra. The diversity of arbitral reactions to discrimination problems buttresses this assumption; $c f$. Wierton Steel Co., 50 Lab. Arb. 795 (1968); Great Atl. \& Pac. Tea Co., 49 Lab. Arb. 1186 (1967) ; Pitman-Moore Div., 49 Lab. Arb. 709 (1967) ; McCall Corp., 49 Lab. Arb. 183 (1967); Studebaker Corp., 49 Lab. Arb. 105 (1967) ; The Ingraham Co., 48 Lab. Arb. 884 (1966). In the racial area see Pangborn Corp., 48 Lab. Arb. 629 (1967); Tri-City Container Corp., 42 Lab. Arb. 1044 (1964) ; Armco Steel Corp., 42 Lab. Arb. 683 (1964); Pittsburgh Metallurgical Co., 38 Lab. Arb. 192 (1962) ; American Sugar Co., 38 Lab. Arb. 132 (1961); cf. American Standard, Inc., 52 Lab. Arb. 736 (1969); Sligo, Inc., 50 Lab. Arb. 1203 (1968). 
The Dewey opinion provides an appealing approach to the election of remedies question. However, there are several objections to be met before it can be applied to racial discrimination grievances. The first, and probably least troublesome, is that Dewey dealt with religious and not racial discrimination. The Dewey court emphasized the fundamental role that freedom of religion plays in our constitutional heritage. However, it certainly cannot be said that racial discrimination is any less vital. ${ }^{62}$ Even a fleeting glance at the thirteenth, fourteenth, and fifteenth amendments indicates that the elimination of racial discrimination is a fundamental policy of our country. In cases involving either of these basic principles of our law, a waiver should not easily be inferred.

Additionally, the arbitrator in Derwey specifically limited himself to contract considerations; as a result, the court quite properly feared that insufficient attention was given to both the title VII and constitutional claims. Thus one could argue against wide application of Dewey that the case should not apply to situations in which an arbitrator has given thorough consideration to title VII and constitutional claims. While consideration of such public law concepts is highly desirable (as the first section of this Article urges) wide adoption of the practice would maximize application of the election of remedies doctrine. It is not a sufficient answer to the problems of racial discrimination in employment for arbitrators merely to consider public law concepts without adopting other reforms. It is also essential to minimize the effect of the election of remedies doctrine, especially if the deficiencies in the arbitration process, which are referred to below, remain unremedied. To some extent the arbitrator's approach in Dewey is dictated by the "fidelity to the contract" doctrine of Enterprise. ${ }^{\text {B3 }}$ But the strict interpretation of Entreprise, combined with the "ab initio" rule of Bowe, will result in (1) lack of uniformity in title VII adjudications, with arbitration decisions (unreviewable by judges) and courts producing substantially different results, and (2) the imposition of a penalty upon the worker for using the grievance procedure. A doctrine which discourages a minority group from using arbitration is at odds with the national labor policy encouraging that process.

Another problem is that, as the Dewey opinion was careful to note, the case involved arbitration and not a grievance settlement entered into with the alleged discriminatee's concurrence (such as in Washington). Thus one could argue that Dewey should be limited to cases in which the discriminatee has not personally indicated satisfaction with a reso-

62 See Jones v. Alfred H. Mayer, 392 U.S. 409 (1968).

63 See text accompanying note 31 supra. 
lution of his case. However, this distinction is not clear-cut; to the extent that the complainant in Dewey initiated the grievance and participated in the proceeding, a certain measure of concurrence can be inferred. Nevertheless, both Washington and Edwards are distinguishable from Dewey in that the plaintiff in those cases actually accepted settlement of the claim. Moreover, a concrete benefit accrued to the party charging discrimination. Certainly, the argument for election of remedies is stronger than in Dewey. However, when it comes to public rights such as those contained in title VII's prohibition of racial discrimination, the objectives of the statute must outweigh the inconvenience done to defendants through a multiplicity of suits. While the national labor policy encouraging arbitration may properly incorporate an election of remedies theory, public policy against racial discrimination outweighs it. There is good reason to believe that the Board's policy toward arbitration awards as a general rule amounts to excessive genuflection to arbitrators. ${ }^{64}$ At the very least, the same policy, let alone a more rigid election of remedies doctrine, ought not to apply in the case of racial discrimination grievances.

Nevertheless, the arbitration award ought not to be disregarded altogether. Courts should evaluate both arbitration awards and settlements in assessing questions of violations and relief. Without creating any kind of presumption against the plaintiff in court, the judiciary should consider arbitration awards as evidence. ${ }^{65}$ One of the problems with a rigid election doctrine is that individuals or groups may not have the advice and assistance of friendly unions or civil rights groups. This should be a consideration in the evaluation of an arbitral award. Dewey, for example, properly considered the fact that the grievant was without counsel in the arbitration proceeding. ${ }^{\text {B6 }}$ Moreover, an award may give the grievant less than that to which he is entitled under title VII. Legislation to eliminate racial discrimination was necessary, because, as a general proposition, power and sophistication are arrayed against the discriminatee. Courts should view with alarm any procedure which would aggravate this problem.

64 See International Harvester Co., 138 N.I.R.B. 923 (1962), enforced sub nom. Ramsey v. NLRB, 327 F.2d 784 (7th Cir. 1964); cf. Cloverleaf Div. Adams Dairy Co., 147 N.L.R.B. 1410, 1415-16 (1964); Raley's Inc., 143 N.L.R.B. 256, 258-59 (1963) ; Spielberg Mfg. Co., 112 N.L.R.B. 1080, 1081 (1955). But see A. O. Smith Corp., 174 N.L.R.B. No. 41, 70 L.R.R.M. 1145, 1147 (1969); Horn \& Hardart Co., 173 N.L.R.B. No. 164, 69 L.R.R.M. 1522 (1968).

65 "[A]s a general proposition, the court doubts that the courts should defer in their consideration of Title VII cases to arbitration awards. [See cases cited note 54 supra.] At the same time, however, the court cannot agree that an arbitration award must be dismissed out of hand as irrelevant and believes that it may properly be considered as an item of evidence, ..." United States v. H. K. Porter Co., 296 F. Supp. 40, 109-10 (N.D. Ala. 1968) (footnote omitted).

60291 F. Supp. at 789. 
The consideration of eliminating racial discrimination in the grievance procedure must also be relied upon in dealing with the most difficult cases-those in which the discriminatee settles and states as a condition of settlement that the right to file a charge and sue in court under title VII is waived. Here the election is explicit and very clear. The question is whether it should be honored in a court. These cases are more troublesome than a contract which prohibits a union from filing an unfair labor practice charge, ${ }^{67}$ or which gives the union exclusive control of all employee claims. ${ }^{68}$ For here, the individual signs the waiver himself and does not proceed through an agent who may not be acting in his principal's best interests. Here again, it is this author's opinion that the public policy against racial discrimination is more basic to the nation than the policy of resolving disputes through private negotiations. One must remember that Vaca hardly makes this kind of waiver an exercise of free choice. ${ }^{69}$ In creating the EEOC and providing statutory muscle for the enforcement of civil rights, Congress has given to the courts some of the means to combat racial discrimination. Public policy requires that the power to remedy unlawful employment practices not be abdicated to another forum.

\section{Third Party Intervention}

The notion that the minority or individual position will not be argued fully without the right of intervention for the grievant has special significance in the case of discrimination charges. The Dewey court recognized this factor when, refusing to bind the plaintiff to an arbitration award, it noted that the plaintiff was not represented with

67 Lodge 743, Int'1 Ass'n of Machinists v. United Aircraft Corp., 337 F.2d 5 (2d Cir. 1964); cf. NLRB v. Strong Roofing \& Insulating Co., 393 U.S. 357 (1969); NLRB v. Acme Indus. Co., 385 U.S. 432 (1967) ; NLRB v. C \& C Plywood Corp., 385 U.S. 421 (1967). See generally McCulloch, The Arbitration Issue in NLRB Decisions, 19 ARB. J. (n.s.) 134 (1964); Ordman, Arbitration and the NLRB, in NATIONAI Academy of Arbitrators, Proceedings of the Twentieth Annual Meeting 47 (1967) ; Sovern, Section 301 and the Primary Jurisdiction of the NLRB, 76 HarV. L. REv. 529 (1963). The Board will sometimes defer jurisdiction until completion of arbitration. See Dubo Mfg. Corp., 142 N.L.R.B. 431 (1963).

68 See article VII, section I of the 1967 Agreement between Ford Motor Co. and UAW which states in part:

No employee or former employee shall have any right under this agreement in any claim, proceeding, action or otherwise on the basis, or by reason, of any claim that any Union Officer representative has acted or failed to act relative to presentation, prosecution or settlement of any grievance or other matter as to which the Union or any Union Officer or representative has authority or discretion to act or not to act under the terms of this agreement. Where there is no arbitration clause see Haynes v. United States Pipe \& Foundry Co., 362 F.2d 414 (5th Cir. 1966) ; International Brotherhood of Telephone Workers v. New England Tel. \& Tel. Co., 240 F. Supp. 426 (D. Mass. 1965).

69 Text accompanying notes 13-15 supra. 
his own counsel at the hearing. ${ }^{70}$ If the discrimination charge involves the administration or negotiation of the collective bargaining agreement (in which, of course, both the union and employer are involved), it is often possible that the union's viewpoint and interests are different from, or conflict directly with, those of the grievants.

The question posed under the rubric of third party intervention is whether the individual or minority group has the right to be notified of the arbitration hearing, and to participate in it with separate representation in the form of counsel or a civil rights organization in which he has confidence. The New York Court of Appeals has held that the individual has no third party right of intervention inasmuch as the union is the exclusive bargaining agent with authority to bind all employees within the union. ${ }^{71}$ Notwithstanding that the Railway Labor Act permits the individual to proceed in his own right through that statute's adjudication machinery (which is controlled by the union and the employer), ${ }^{72}$ the NLRB has taken the position that it will honor an arbitration award even when the individual has no notice of the hearing. Therefore he has no right to representation. ${ }^{73}$ The Board's judgment is that even where the case involves an individual's discharge pursuant to a union security clause, the discharged employee's absence does not destroy the hearing's validity so long as the employer takes a position at the hearing identical to that asserted by the individual. ${ }^{74}$

In Clark v. Hein-Werner Corp., ${ }^{75}$ a case involving a seniority dispute, the Wisconsin Supreme Court has taken a slightly different approach. In Clark the court held that a union was not performing its "fiduciary" duty of fair representation in a case involving conflicting employee claims. The court said that

where the interests of two groups of employees are diametrically opposed to each other and the union espouses the cause of one in the arbitration, it follows as a matter of law that there has been no fair representation of the group. This is true even though, in choosing the cause of which group to espouse, the union acts completely objectively and with the best of motives. The old adage, that one cannot serve two masters, is particularly applicable to such a situation. ${ }^{78}$

70291 F. Supp. at 789.

71 In re Soto, 7 N.Y.2d 397, 165 N.E.2d 855, 198 N.Y.S.2d 282 (1960). However, see the strong dissent of Judge VanVoorhis in Chupka v. Lorenz-Schneider Co., 12 N.Y.2d 1, 7; 186 N.E.2d 191, 193; 233 N.Y.S.2d 929, 932 (1962).

72 McElroy v. Terminal R.R. Ass'n, 392 F.2d 966 (7th Cir. 1968) ; Estes v. Union Terminal Co., 89 F.2d 768 (5th Cir. 1937).

73 International Harvester Co., 138 N.L.R.B. 923 (1962), enforced sub nom. Ramsey v. NLRB, 327 F.2d 784 (7th Cir. 1964).

$74 I d$. at 928 .

758 Wis. 2d 264, 99 N.W.2d 132 (1960).

$76 I d$. at 272,99 N.W.2d at 137. 
Concerning the argument that the employees' positions were considered by the arbitrator because the employer took the position of the plaintiffs at the hearing, the court said:

Employees not fairly represented by the union should never be put in the position of having solely to depend upon the employer championing their rights under the collective-bargaining contract. ${ }^{77}$

In Humphrey v. Moore, ${ }^{78}$ the Supreme Court considered an assertion that granting a right to employees to participate in the hearing was a necessary element in the duty of fair representation. The Court found that contrary to the dissident workers' allegations, they had in fact participated fully. ${ }^{79}$ Nevertheless, one can conclude that the Court impliedly accepted the position that the right to intervene is part and parcel of the union's obligation to represent fairly, since the Court examined the issue factually rather than dismissing as a matter of law. However, we must keep in mind that conflicting seniority claims of two different groups of employees were involved, and for the reasons enumerated in Clark, the Court may have been particularly sensitive to the third party intervention argument in this context.

However, despite Clark and Humphrey, the case law shows no uniform trend toward a policy favoring third party intervention. In fact, any hope of adoption was recently set back by the Fifth Circuit's decision in Acuff v. United Papermakers. ${ }^{80}$ In Acuff an arbitrator rejected the grievance of certain discharged employees and reduced the discharge of others to disciplinary layoff, following a wildcat strike. The employees subsequently filed in the district court which had ordered the arbitration a motion to intervene. The court ignored Humphrey and relied heavily on $V a c a$ for the proposition that third party intervention would interfere with the union's right to control the grievancearbitration process. After citing $V a c a$ 's rule that the union, and not the individual, has the right to compel arbitration of a grievance, the court stated:

It would be paradoxical in the extreme if the union, which is authorized to decide whether a grievance is to be pursued to the arbitration stage at all could not be authorized to assume

$7 \tau$ Id. at 275,99 N.W.2d at 138.

78375 U.S. 335 (1964).

79 Id. at 349-351.

30404 F.2d 169 (5th Cir. 1968), cert. denied, 394 U.S. 987 (1969). 
full responsibility for a grievance it did pursue, without the intervention of the individual union members immediately concerned. ${ }^{81}$

Assuming the validity of the holding in Clark, the court stated that Acuff was distinguishable inasmuch as "it [Clark] is a different case if the interests of different groups of employees are in irreconcilable conflict. Here the union could have and, as far as the record reveals, did defend the rights of all the employees with equal zeal." $\$ 2$

However, Acuff is in error contrasting Clark. Although the potential conflict of interest in exclusive union representation of wildcat

$81 \mathrm{Id}$. at 171. It will be recalled that the Court's holding in Vaca is predicated in part upon the exclusive bargaining representative status which is accorded unions under the NLRA. See J. I. Case Co. v. NLRB, 321 U.S. 332 (1944). However, section 9(a) contains a proviso which indicates that

any individual employee or a group of employees shall have the right at any time to present grievances to their employer and to have such grievances adjusted, without the intervention of the bargaining representative, as long as the adjustment is not inconsistent with the terms of a collective-bargaining contract or agreement then in effect: Provided further, that the bargaining representative has been given opportunity to be present at such adjustment.

National Labor Relations Act $\$ 9$ (a), 29 U.S.C. $\$ 159$ (a) (1964). See generally Hanslowe, Individual Rights in Collective Labor Relations, 45 CoRNenL L.Q. 25 (1959); Rosen, The Individual Worker in Grievance Arbitration: Still Another Look at the Problem, 24 Maryland L. REv. 233 (1964); Summers, Individnal Rights in Collective Agreements and Arbitration, 37 N.Y.U. L. Rev. 362 (1962). The Second Circuit has extended the proviso to protect a rival union in processing grievances in the face of an exclusive bargaining representative's existence. See Douds v. Local 1250, Retail-Wholesale Union, 173 F.2d 764 (2d Cir. 1949). But see Dunau, Employee Participation in the Grievance Aspect of Collective Bargaining, 50 CouUn. L. REv. 731, $751-760$ (1950) ; Broniman v. Great Atl. \& Pac. Tea Co., 353 F.2d 559 (6th Cir. 1965) ; Black-Clawson Co. v. IAM Lodge, 355, 313 F.2d 179 (2d Cir. 1962) ; Federal Tel. \& Radio Co., 107 N.L.R.B. 649 (1953). See especially Republic Steel Corp. v. Maddox, 379 U.S. 650, 652, n.7 (1965) ; cf. Restaurant Management, Inc., 147 N.L.R.B. 1060, 1069, n.21 (1964) ; Dist. 65, Retail-Wholesale Union, 141 N.L.R.B. 991, 999 (1963) ; Mission Valley Inn, 140 N.L.R.B. 433 (1963); Fanelli Ford Sales, Inc., 133 N.L.R.B. 1468 (1961); Weiss, The Unlareful Object in $8(b)(7)$ Ficketing, 13 LABOR L.J. 787 (1962).

It will be argued that the intervention of a civil rights group in an arbitration contrary to the Acuff rule in effect supports the existence of another "labor organization" and is therefore at odds with the exclusive representative concept. See NLRB v. Cabot Carbon Co., 360 U.S. 203 (1959); National Packing Co., 147 N.I.R.B. 446 (1964), enforcement denied and remanded, 352 F.2d 482 (10th Cir. 1965), original order aff'd, 158 N.L.R.B. 1680 (1966), enforcement denied and rev'd, 377'F.2d 800 (10th Cir. 1967); NLRB v. Draper Corp., 145 F.2d 199 (4th Cir. 1944). See generally Gould, The Status of Unauthorized and "Wildcat" Strikes under the National Labor Relations Act, 52 CoRnell L.Q. 672 (1967). The question whether the existence of civil rights groups in the arbitration or at some stage of grievance processing or negotiations where they present some working demands is compatible with the majority representative concept, has not been answered definitively by the Board. NLRB v. Tanner Motor Livery, Ltd., 349 F.2d 1 (9th Cir. 1965), affirmed, 166 N.L.R.B. No. 35 (1967). However, probably no conflict between the exclusive bargaining representative and the civil rights organization would exist unless the latter attempted to oust the former from his representative capacity. Sometimes this line may be an elusive one to draw. See Moss-American, Inc., 178 N.L.R.B. No. 30 (1969).

82 Acuff v. United Papermakers, 404 F.2d 169, 171 n.3 (5th Cir. 1968). 
strikers is not quite as direct as it is in a seniority dispute, as was involved in Clark, nevertheless there is not such a difference between the two that they should be decided differently. In an unauthorized stoppage a union has a strong interest in guarding its treasury against strike liability. If the union can be shown to have instigated or aided the walkout, it may be liable for damages. ${ }^{83}$ At the same time, the union is obliged to argue for reinstatement or for scaling down of penalties on behalf of the strikers. A striker might testify that a union officer or committeeman told him to "down tools"-in other words, that the walkout was not something initiated by workers independent of their union. Might not some unions wish to keep such a grievant away from the hearing and without representation, even though the result would be discharge or suspension for the offending worker? These kinds of dilemmas for the union, as well as the fact that a perusal of the hearing transcript (if one is kept) can rarely inform a court on the enthusiasm with which the union presented the case, make the Fifth Circuit's search of the record for union zeal irrelevant and futile.

Second, the court's conclusion that it would be "paradoxical" to provide for third party intervention in light of $V$ aca is curious. If anything, the control that Vaca affords the union in discharging its responsibilities would argue for a limited right such as intervention for those who might be out of favor with the exclusive bargaining representative. Under $V a c a$, unions will have little difficulty in refusing to take to arbitration those cases in which third party intervention might cause them substantial discomfort. To say that because the union has authority to interfere with the individual's right to compel arbitration, third party intervention is to be denied once arbitration is underway, defies common sense and sound logic.

When one considers the question of third party intervention in the context of title VII racial discrimination grievances, it is important to recall the Court's remarks in Lincoln Mills about the judicial role in section 301(a) labor arbitration suits:

[T] he substantive law to apply in suits under $\S 301$ (a) is federal law, which the courts must fashion from the policy of our national labor laws. . . . The Labor Management Relations Act expressly furnishes some substantive law. It points out what the parties may or may not do in certain situations. Other problems will lie in the penumbra of express statutory mandate. Some rill lack express statutory sanction but will be solved by looking at the policy of the legislation and fashioning a remedy that will effectuate that policy. The

83 See United Constr. Workers v. Haislip Baking Co., 223 F.2d 872 (4th Cir. 1955) (dictum). 
range of judicial inventiveness will be determined by the nature of the problem. ${ }^{84}$

One must assume that title VII is one of the statutes to which the Court is to pay heed in fashioning remedies that do not possess "express statutory sanction," but nevertheless lie in the "penumbra" of the statute's mandate. In enacting title VII, Congress recognized that black workers were under-represented at the bargaining table, excluded unfairly and arbitrarily from leadership positions in unions (even when their numbers were large, because generally whites will not vote for blacks in union elections ${ }^{85}$ ), and were dealt with unjustly at the bargaining table by both unions and employers. ${ }^{86}$ Title VII was passed to remedy, among other things, the unique problems of racial minority groups in the United States, which majority representatives in many organized enterprises failed to solve. Considering this policy, courts should seize the opportunity presented by Lincoln Mills to order either a form of trilateral arbitration (if a civil rights organization has entered into an agreement over hiring with an employer), or third party intervention where appropriate. Objection may be made that the entry of a third party would unduly disturb the uniformity in administering plant grievances-a principle emphasized in both Maddox and $V a c a-$ but the answer must be that " $[t]$ he rationality of the exhaustion doctrine is dependent upon the fairness of the process to which the individual is remanded." 87

In Hotel Employees Association ${ }^{88}$ an arbitrator invalidated a civil rights agreement without the presence at the arbitration proceeding of the organization which negotiated it. It is certainly possible that notice to the organization and the opportunity to participate in the hearing would have exposed the arbitrator to the full clash of opposing viewpoints which should be an integral part of a hearing procedure. Perhaps the judiciary should either vacate the award or refuse to compel arbiadded).

S4 Textile Workers Union v. Lincoln Mills, 353 U.S. 448, 457 (1957) (emphasis

${ }^{85}$ See generally Gould, Black Workers in White Unions, THE Natron, September 8, 1969, at 203; Gould, The Negro Revolution and Trade Unionism, in 114 Cong. REc. E7226-28 (daily ed. Aug. 1, 1968).

86 See generally Comment, Equal Protection, 82 HARv. L. REv. 1065 (1969); Comment, The "New" Thirteenth Amendment: A Preliminary Analysis, 82 Harv. L. REv. 1294 (1969) ; Jones v. Alfred H. Mayer Co., 392 U.S. 409 (1968). As Justice Douglas said: "Today the black is protected by a host of civil rights laws. But the forces of discrimination are still strong." Id. at 447 (concurring opinion).

87 Note, Federal Protection of Individual Rights under Labor Contracts, 73 YaLE L.J. 1215, 1228 (1964). Moreover, under title VII, the complainant is not bound to a settlement negotiated by the Equal Employment Opportunity Commission unless the complainant agrees to be bound. See EEOC General Counsel Opinion Letter, July 20, 1966, in BNA FAIR EMr. PRAC. 401: 3009; Cox v. United States Gypsum Co., 284 F. Supp. 74 (N.D. Ind. 1968).

8847 Lab. Arb. 873 (1966). 
tration where such notice is not given in racial discrimination cases. ${ }^{89}$ As the courts have already acknowledged in the exhaustion cases, title VII and racial discrimination stand on a special plateau. ${ }^{90}$

However, the practical problems involved cannot be gainsaid. One such problem would arise if a civil rights organization sought to intervene without any indication that Negro or other minority group workers desired intervention. In such a situation, the demands of what is, in effect, an interloper ought to be firmly denied. Only the minority group workers' designee should be permitted to participate.

Another objection is that many groups or individuals might desire to participate in the arbitration if a third party intervention or similar rule were promulgated. Obviously, since a large number of intervenors would pose practical problems of orderliness, courts and arbitrators ought to require that a reasonably substantial number of workers request the involvement before intervention in the arbitration process is permitted.

Although third party intervention may appear at first glance to be a radical proposal, in fact it should result in minimal distuption of the arbitration process. In many grievances, particularly discharges, the union-partially because of its omnipresent duty of fair representationwill process the grievance in a manner which will not make it necessary for the worker to involve a third party. Or, those unions which do not like the grievant or his case may invite participation to avoid a lawsuit. Moreover, some arbitrators already insist upon hearing the testimony and requiring the attendance of individual employees when there is the slightest indication of divergence of viewpoints between union and employee. Finally, the principle of exclusivity and majority rule is well protected by Supreme Court decisions such as Vaca. Indeed the most telling argument against intervention is that unions will eventually become too selective in taking cases to arbitration. But to a large extent, $V a c a$ already encourages this result. In any event, a third party intervention requirement such as that advocated here would seem to do little damage to the $V$ aca principle. While adoption of the third party intervention proposal ought not to be used to weaken the preceding arguments against the election of remedies doctrine or even to support application of the Spielberg doctrine ${ }^{91}$ to racial discrimination grievances, both EEOC and the courts would properly accord greater deference to the arbitral process and its decisions, if this proposal is accepted along with other proposals offered below.

89 See Gould, Non-Governmental Remedies for Employment Discrimination, supra note 6.

80 Cases cited note 21 supra.

91 Spielberg Mfg. Co., 112 N.L.R.B. 1080, 1082 (1955). 


\section{Patching Up the Leaky Ship}

Various additional remedial devices could be used to improve the lot of the minority group worker who is inadequately represented by his union. As noted above, one of the problems in the arbitration of racial grievances is that unions and employers themselves select third party representatives. Where, as in Hotel Employers Association, the arbitrator construes both the civil rights agreement and the collective bargaining agreement, all parties ought to be involved in selection of the arbitrator as well as in the proceeding itself. In the somewhat analogous situation of two unions entangled in a jurisdictional dispute, the Supreme Court rejected the argument that trilateral arbitration is a requirement if only one of them is a party to the arbitration and contract involved. $^{92}$ However, the Court's holding in Lincoln Mills-that remedies will be fashioned in light of the total body of national labor law-makes possible a different result in the case of racial discrimination.

Even with the contractual base of a civil rights agreement, the remedy for discrimination and violation of the union's duty of fair representation should recognize the triangular nature of the racial grievance. This is exactly what was done by the trial examiner in Port Drum Co., ${ }^{93}$ who ordered that no arbitrator or counsel representing the charging party's interests was to be appointed without the charging party's prior written approval and consent. However, a unanimous Board modified the order so that, as in Rubber Workers, ${ }^{94}$ the union would be obligated merely to take the grievance to arbitration. But the effect was mitigated somewhat when the Board held, while setting aside another portion of the trial examiner's order obligating the union to make the charging party whole in the event that "resort to arbitration or fully effective relief [was] . . . now . . . barred or precluded and cannot be forthcoming," that it would retain jurisdiction so that the hearing might be reopened subsequent to the arbitration..$^{95}$

Second, if title VII is to be used by arbitrators where nondiscrimination or separability clauses present the opportunity, the arbitrators must be advised by those who possess expertise in matters foreign to their experience. ${ }^{98}$ Thus Congress should amend title VII to provide

22 See Carey v. Westinghouse Elec. Corp., 375 U.S. 261, 265 (1964); id. at 274 (dissenting opinion).

93 CCH NLRB Dec. $\llbracket 22,272$ (1968).

94150 N.L.R.B. 312, enf'd on this point, 368 F.2d 12 (5th Cir. 1966).

$95 I d$.

96 One should recall that the arbitrator's expertise, albeit valuable and important, is in other areas. See United Steelworkers of America v. Enterprise Wheel \& Car Corp., 363 U.S. 593 (1960). 
for an advisory opinion on title VII issues raised in the hearing. These opinions could be rendered by the EEOC pursuant to the request of the arbitrators or the parties. Perhaps EEOC should be required to provide the parties with the advisory opinion even when not requested, when a grievance alleging racial discrimination is brought to their attention by a party. Another alternative (one that might be more orderly) is to require the arbitrator to request the opinion.

Additionally, when EEOC enters into conciliation agreements, ${ }^{97}$ it could obtain the expertise and flexibility of arbitration by special arbitration clauses to deal with such issues as seniority disputes. The Commission ought to begin to exercise substantial authority in the selection of the arbitrator, and it might be beneficial for it to maintain a list of neutrals whom it considers acceptable. A source for such arbitrators might be the American Arbitration Association Center for Dispute Settlement, which is involved in minority group disputes.

Finally, an arbitral remedy arguably consistent with the general intent of the nondiscrimination and separability clause is that employed in Phillips Petroleum Co. ${ }^{98}$ In that case the arbitrator, while rejecting the contention that the company's refusal to appoint a woman to its credit trainee program was discrimination by sex, nevertheless noted that not one of the 118 trainees previously appointed was a woman. The arbitrator's award stated that if the union had not already filed a complaint, the company would request the Missouri Human Rights Commission to make an evaluation of past and present policies of candidate selection for the trainee program.

This author believes that the Phillips approach is laudable and proper, although it may not have been fully contemplated by the parties. ${ }^{99}$ However, where there is no group of discriminatees already employed in the particular establishment, as in the Phillips case itself, one wonders whether such an award will in fact be effectuated. In Phillips Petroleum Co., investigation revealed that subsequently neither the union nor the employer had contacted the Commission. ${ }^{100}$ If the arbitrator were to undertake this function himself, most likely the parties would feel, and rightfully so, that he had exceeded his authority. Even unions and employers that negotiate nondiscrimination clauses in good faith do not wish to invite the EEOC and similar state agencies onto plant

9742 U.S.C. $\$ 2000 \mathrm{e}$ (5) (a) (1964).

9850 Lab. Arb. 522 (1968).

99 This ought not to restrain the arbitrator from acting. Cox, Rights Under a Labor Agreement, 69 HARv. L. Rev. 601 (1956).

100 Telephone conversation between research assistant James VeuCasovic and Miss Sandra Neece, Director of Investigation for Missouri Human Rights Commission, May 29, 1969. 
premises-hardly anyone appoints an arbitrator to perform this task for them. Rather, their thought is to resolve discrimination problems without such complications.

\section{Concluston}

The analysis and proposals outlined in this Article would modify in large part the voluntary and private nature of labor arbitration. They run against the grain of much of the conventional wisdom contained in the national labor policy devised since the War Labor Board gave arbitration its real beginning in the United States some twenty-five years ago.

Most likely one must also accept the proposition that the adoption of approaches taken in this Article may result in a revision of our industrial relations system beyond racial disputes. Other minorities and individuals in nonracial cases will insist upon the application of the same standards in all arbitrations where, for one reason or another, the union is not trusted by those whom it represents. Perhaps, though, the extension of title VII advocated here, in an age in which union leadership seems so remote to the rank and file worker, is a step in the right direction in industrial relations generally.

There is no reason why the rules of third party intervention herein advocated cannot be fashioned in both racial and nonracial cases in a manner which avoids excessive disruption. ${ }^{101}$ Here, as in other situations, the Negro revolution may reform our institutions to the benefit of both races. But the theme of this Article is that America is obligated to devise special procedures for racial problems-particularly in the case of black workers. It is not proposed that the majority rule principle be scrapped in favor of another doctrine. What is suggested amounts to an accommodation of that principle with procedures more effectively designed to achieve the objectives of civil rights statutes. The left hand of national labor law cannot perform in ignorance of what the right hand is doing.

The most troubling aspect about the positions taken in this Article is whether the leaky ship is worth patching. One might well argue that it is better to build a new ship constructed in the form of government labor courts more responsive to public law. That solution is a more ambitious undertaking which can be left to others. For the moment, we must modify those procedures already available. Equity for the black worker cannot be permitted to await fundamental labor law reforms in the distant future. 
It is too late for those involved in arbitration, or for the trade union movement generally, to complain about limited regulation by public law concepts. If ever there was an area in which the value of consensual arrangements is clearly outweighed, it is found in the attempt to eliminate the systematic discrimination which government, unions, and employers historically have practiced against the Negro worker. 